Bulletin of Taras Shevchenko National University of Kyiv. Public Administration, 1(15), 28-32. UDC: 351.

DOI: doi.org/10.17721/2616-9193.2022/15-6/9

Lester C. Reams, Prof., Dr. of Public Administration, Juris Doctor Mount Saint Mary's University, Los Angeles, California, USA https://orcid.org/ 0000-0002-6883-7072 email: Ireams@msmu.edu

\title{
THE MINDSET BEHIND THE SILENT DISCRIMINATORY AND RETALIATORY CONSPIRACY OF CONSTRUCTIVE DISCHARGE
}

\begin{abstract}
Over the years employees have faced situations when their actions that previously received praise, were now seen as disruptive. Performance standards and reviews have changed so that the employee is under-performing. Colleagues that were once supportive become distant, critical or avoid interaction. Because of these changes the employee makes the decision to leave because of the intolerable working conditions, allowing management to conclude that the employee was at fault. This article analyzes the business mindset of upper management that engages in the silent discriminatory and retaliatory conspiracy of constructive discharge. Psychological, cognitive, legal and economic factors involved are analyzed with the use of grounded theory, case studies, legal and managerial analysis. Based on the discussion of legal and workplace environment, the author formulates recommendations for business and public institutions to implement.
\end{abstract}

Key words: Business mindset, constructive discharge, business and public organizations, human capital management

Introduction. Over the years employees have faced situations where for some reason the workplace that they knew has suddenly turned against them. Their actions that received praise and accolades are now seen as disruptive. Performance standards and reviews have changed where the employee is under-performing. Colleagues that were once supportive have now become distant, critical or avoid interaction. What the employee does not know is that all of these changes have happened silently where only a few employees know and participate in carrying out these changes. Because of these changes the employee makes the decision to leave because of the intolerable working conditions, allowing management to conclude that the employee was at fault. The purpose of this article is to analyze the business mindset of upper management that engages in the silent discriminatory and retaliatory conspiracy of constructive discharge.

Business Mindset Overview. A business is an organization which seeks to make a profit through individuals working toward common goals [19]. In working toward a common, the employers' focus is to create work environment where employee can be productive, contribute ideas when possible and meet the employers expectations. This means the employers and employees work cooperatively with each other.

Mindset is defined as a set of assumptions, methods, or notions held by one or more people or groups of people [15]; a person's way of thinking and their opinions [4]. A mindset can also be seen as arising out of a person's world view or philosophy of life [11]; it is defined in dictionaries as "a fixed mental attitude or disposition that predetermines a person's responses to and interpretations of situations" [21], "the ideas and attitudes with which a person approaches a situation, especially when these are seen as being difficult to alter. (World English Dictionary: quoted from: Sources of Insight).

Variously conceptualized across disciplines [10], the concept of mindset is associated with individual and collective perceptions, beliefs, attitudes, worldview, motivation, decision-making, and action [12]. The types of mindsets explored by cognitive psychologists are classified based on different criteria, depending on the author's research focus: growth mindset vs fixed mindset [8], deliberative mindset vs the implemental mindset $[12 ; 6]$ etc. When researching the business discipline, it has been found that it carries with it certain norms and traditions that has led to it own mindset.

Based on these norms and traditions the business mindset has become an important distinctive value of the American society which for centuries has driven its development as well as perception and interpretation of events and the respective actions. What has been the discussion of the business mindset is so interesting because it allows research to determine why a CEO, Entrepreneur or small business owner would resort to both positive and negative behavior in the business environment. Often there are two sides to coin: face and back. On the one hand, a CEO, entrepreneur, or small business owner can create a health and safe work environment. On the other hand, the same CEO, entrepreneur, or small business owner can use tools that creates a very toxic work environment where a symptom is a high absentee rate, poor performance, and poor morale which ultimately leads to employee resignations or terminations. Such is the cases in the development of tools such as non-compete clauses, non-disclosure agreements and the use of constructive discharge.

History of the Business Mindset. In his book "The Age of Betrayal" (2007) Jack Brady indicated that it was not until after the civil war, during the Unites States' industrial revolution, that the influence of business would take place. This revolution was known as the Gilded Age which began in 1870 and ended in 1900. The term Gilded Age was used by historians in the 1920s, who took the term from one of Mark Twain's lesser-known novels, The Gilded Age: A Tale of Today, 1873 [2]. It was during this time that the United States' business mindset was firmly established through the Gilded Age robber barons James J. Hill, Henry Ford, Andrew Carnegie, Cornelius Vanderbilt, and John D. Rockefeller and others. Brady pointed out that although the industrialization of the United States brought wealth to a handful of people, this industrial revolution left the remaining citizens to struggle as wage laborers. John Naughton (2012) summed up the behavior and mindset of business when he stated: "In addition to building a modern industrial state, these gents amassed huge fortunes for themselves using a raft of dubious techniques, including fraud, stock-dilution, the bribing of corrupt politicians, the creation of secret cartels (ironically called "trusts") and the ruthless exploitation of poorly paid, non-unionized workers 
- which is why Matthew Josephson dubbed them "robber barons" in his book of the same title" [17].

Since the Gilded Age, the wealthy have managed to stay in power to protect their own self-interest either through money, lobbyism or becoming politicians. While this has been beneficial for the wealthy, small and medium size businesses have not had the opportunity to participate unless they have become members of organizations that represent their interest, such as local Chamber of Commerce or business associations. One aspect that is encouraged by large corporations and business consultants is that small and medium size business owners incorporate tools and approaches that have been used by corporations so that small or medium size businesses can protect their self-interest by eliminating potential threats such as competitors or specific employees and maximize their profits as well.

During the $21^{\text {st }}$ Century, although there has been an attempt to redefine the business mindset as a way of thinking that enables a person to resolve problems, Naughton (2012) concluded that new tech moguls such as Mark Zuckerberg, Jeff Bezos and others may look cool and have soothing bedside manners, but in the end these guys are in business not just to make money, but to establish sprawling, quasi-monopolistic commercial empires. And they will do whatever it takes to achieve those ambitions" $[17$, p. 5]. This implies that any threats to those ambitions will be eliminated. Therefore, the business behavior of using constructive discharge has been an approach used to eliminate employees that pose a threat that could disrupt or even stop those ambitions.

Constructive Discharge. To understand it is important the focus will be to define constructive discharge, describe the legal definition of a hostile environment and identify the business mindset that creates a hostile work environment and intolerable working conditions.

Definition of Constructive Discharge. Situations that are considered a hostile workplace have been defined by various Federal Laws [18]. However, the strengthen of these laws occurred when the U.S. Supreme Court extended the legal concept of constructive discharge to cases brought under Title VII of the Civil Rights Act of 1964, the Age Discrimination in Employment Act (ADEA) of 1967, and the American Disabilities Act of 1990 (EEOC, n.d.). The Equal Employment Opportunity Commission (EEOC) became the federal agency that regulates employer issues such as harassment and discrimination. These laws indicated that a workplace qualifies when there is inappropriate conduct in which a person is harassed or discriminated based on the protected classes of race, color, religion, sex (including pregnancy), national origin, age (40 or older) . (EEOC, n.d.). Finally, the test that is used by the law is the question, would a reasonable person find the environment to be hostile or abusive? [18].

Definition Intolerable Working Conditions. England (n.d.) has indicated that intolerable working conditions occurs when an employer engages egregious conduct that is so bad, such as physically harassing the employee or demoting him or her in a humiliating way, where the resigning person must prove that the average person in the same situation would also have been compelled to resign (Ibid). Unfortunately, this is a high standard which is very difficult to prove if the conduct has not reached this level (Ibid).

Misconception. Common misconceptions of a hostile work environment stems from the type of employee behavior that: (a) does not qualify as a hostile work environment and intolerable working condition and (b) workplace bullying.

a. Does not qualify as Hostile Work Environment and Intolerable Working Condition

One of the common misconceptions regarding a hostile work environment is that there are loud/noisy coworkers, the conditions are unpleasant, feeling overworked, underpaid, unhappy, bad obnoxious bosses and coworkers or a lack of general support. The characteristics stated above is part of the reality of work and would not constitute a hostile work environment and intolerable working condition.

\section{b. Workplace Bullying}

The next common misconception regarding hostile work environment is that it is workplace bullying. The Workplace Bullying Institute (WBI) defines workplace bullying as the repeated, health-harming mistreatment by one or more employees of an employee. This mistreatment takes the form of verbal abuse, behaviors perceived as threatening, intimidating, or humiliating, work sabotage; or in some combination of the above. (Namie and Namie, n.d.). Bachman (2019) adds that while workplace bullying has a damaging effect at the workplace, there is no federal law that makes the practice illegal. This is the reason that workplace bullying does not constitute a hostile work environment and intolerable working condition.

Business Mindset that Creates a Hostile Work Environment and Intolerable Working Condition. John Naughton (2012) summed up the behavior and mindset of business indicated that the robber barons would use a raft of dubious techniques, including fraud, stock-dilution, the bribing of corrupt politicians, the creation of secret cartels (ironically called "trusts") and the ruthless exploitation of poorly paid, non-unionized workers [17, p. 5-6]. This characterization has been prevalent since the $20^{\text {th }}$ century which has led to the business mindset that contributes to the creation of a hostile work environment and intolerable working conditions.

Gordon (2020) has identified the specific mindset that has developed as part of the ruthless exploitation behavior that is exhibited when employees are bullied. These mindsets are as follows:

1. Feeling of inferiority-The leaders or workers feel inferior or they worry that their work is being overshadowed when a coworker or supervisor works with a skilled employee. These leaders or coworkers will either steal the credit or undermine the skilled employee.

2. Feeling threatened - the leaders or workers feel threatened when an employee poses a threat due to their own popularity and social status at work.

3. Form cliques - the leaders or workers form cliques and target others who threaten their status or social standing. If the clique promotes into upper management, it will later become the dominant culture. The clique will hire people that continue to behave in the same manner.

4. Loss of control - the leaders or workers want to be in control and call all the shots. If a worker is a team-builder this will threaten their control.

5. Stereotypical or Prejudicial behavior - the leader or workers will stereotype and single out workers that are different or weaker than they are at work.

As a result of the above mindsets, the target employees will experience verbal abuse, sexual harassment, threats, humiliating behavior, and bullying.

How is it used by the employer in the workplace? 
How constructive discharge is used can vary among organizations. When used constructive discharge is done silently making it difficult to detect. The following are the way that it has and continue to be used in the business.

Discourage Unionization and Force Resignations. Historically, in the 30's, constructive discharge was used by employers to oppose the formation of unions (England, n.d.). The organization profits were threatened because the unions would be used to collectively negotiate for higher pay rates, more benefits, and better working conditions (Ibid). These employers used a variety of measures to construct intolerable working conditions which included the use of physical violence to discourage employee unionization and force some employee to resign to avoid suffering due to employer abuse (lbid).

Employer Targeting. For constructive discharge to occur, the employer must target specific employees. The easiest factor for targeting is employee performance. If the employer has established clear expectations that the employee is not meeting, the employer has the right to target the employee with the purpose of working with the employee to make the necessary improvements so that the employee can perform as the expected level. Where the problem occurs is if the employers mindset for targeting the employees performance is due to feeling threatened, inferior, loss of control or based on stereotypical or prejudicial behavior [13]. It is not uncommon for the employer, based on these mindsets, to manufacture a performance issue because of either the popularity of the employee or the employee unwillingness to submit to the dominant toxic culture at the workplace. This targeting will lead to the employees resignations.

Characteristics. The characteristics tend to focus on the culture that has been created and whether the organization has been held accountable. These characteristics are as follows:

a. Operate Freely: For example, if in one state businesses are allowed to operate freely with minor regulations, oversight and lack of accountability, the organization may use practices that may appear questionable, such as nepotism, misrepresentation, immoral hiring practices, pay disparity among employees and others. Unfortunately, even in states where there are heavy regulations, constructive discharge can still be used because the high standard is difficult to prove, as mentioned earlier. Hence, employees did not have any recourse to address the matter which will results in their resignation.

b. High Employee Turnover: Organization that have a high employee turn may use constructive discharge to keep a steady flow of employees to avoid having to pay high salaries except to a selected few.

Financial Status. The financial status of an organization may have an impact on whether constructive discharge is used as well. For instance, if the organization is no longer as profitable as in previous years and wants to avoid having to pay unemployment benefits, dismissal compensation or severance packages, it may choose to use constructive discharge to target key employees that are perceived as a threat and currently receiving high salaries where the organization provides a matching retirement benefit.

Green v Brannan. The common example that illustrates how an organization has used constructive discharge is the Green v Brannan case. In Green v. Brannan (2016), Marvin Green tried to bring a wrongful termination lawsuit against the United States Postal Service (USPS). He claimed that he was constructively discharged when he did not get a promotion and was told that he could either resign or be demoted and relocated to another state [14]. Mr. Green believes that this action was taken because of his race. He contends that he was forced to quit (constructively discharged) when this happened.

Why is it a silent discriminatory and retaliatory Conspiracy?

It is important to identify why the constructive discharge is a silent discriminatory and retaliatory and a conspiracy.

Silent Discriminatory and Retaliatory. As mentioned earlier constructive discharge is very difficult to detect because it is a silent form of discrimination aimed at retaliating against unsuspecting employees. The reason that it is silent is because it is subjective and based on the employers observations and specific mindset identified by Gordon (2020). It is also silent because the employers have created neutral employment policies and practices that were questionable but did not the violate the NLRB in the National Labor Relations Act ("The Act") and later the EEOC. These policies and practices will allow the employee to discriminate and retaliate against the unsuspecting employee as part of the policies and practices. Unfortunately, these policies and practices did not include some form of punishment which would discourage the discriminatory or retaliatory practice but were seen as suggested policies and practices. When audited the organization could indicated that it does have practices and policies in placed that do not violate federal or state regulations. While this is true, the practice and policies did very little to stop the use of constructive discharge.

Conspiracy. A conspiracy is defined as an agreement between two or more persons to commit an unlawful act or to accomplish a lawful end by unlawful means [3]. In order for constructive discharge to be effective it has to be supported by other employees who will serve as witnesses. Per Gordon (2020), cliques are formed that supports the employer. For example, the cliques will consist of upper management, supervisors and favored employees [13]. These cliques will target those employees identified by a clique member and slowly make the work environment difficult for that person. In instances where there is a conflict between a targeted employee and the clique member, upper management will favor the clique. With this concerted approach in place, the actions of the clique members will contribute to targeted employee decision to resign from the organization.

How has Constructive Discharge Impacted the Business Environment?

Constructive Discharge has impacted the employee and employer in the business environment in the following manner.

Employee. Prior to the 1930s as part of the business mindset established by the "Robber Barons" employees did not have much of a recourse when it came to mistreatment and terminations from the worksite. With the introduction of The Act in the 30's other legislation was created that protected the employee. In the last decades, the U.S. Supreme Court has extended the legal concept of constructive discharge to cases brought under Title VII of the Civil Rights Act and the Age Discrimination in Employment Act (ADEA), the federal laws that prohibit discrimination and harassment in employment. Green v Brennan (2016) discussed earlier provided a ruling where instead of following the requirement that plaintiff must bring his complaint to the Equal Employment Opportunity 
Commission (EEOC) within 45 days, the U.S. Supreme Court ruled that for claims of constructive discharge, the clock begins to run when a notice of resignation is submitted which is equivalent to wrongful termination claim [14]. This ruling provided future constructive discharge plaintiffs with more time to file cases.

The impact that legislation and U.S. Supreme Court ruling has had on the business environment has led to an increase in the number of legal actions. Because of this the employer has been forced to redesign the work environment. COVID 19 has also had an impact to where it is now an employee's market where the employee will not return to work until there is a change in the work environment and working relationship between the employer and employee. Hence, this change may decrease the number of constructive discharge cases.

Employer. As a result of the laws protecting employees from constructive discharge, employers have faced severe penalties when a former employee wins a constructive discharge case. Thorne (1994) indicated that the usual penalties consist of the following.

1. Back pay - the amount of wages the employee would have been paid had they continued working for the company until the time of the lawsuit.

2. Front pay - an amount based on the employee's remaining work years and the expected length of time it takes him or her to find a similar job.

3. Reimbursement of attorney fees.

4. Finally, monetary damages, compensatory damages for pain and suffering or mental distress, and punitive damages of up to $\$ 300,000$ in some discrimination cases.

Thorne (1994) added that due to the impact that the penalties may have on businesses, some states have enacted legislations that has made the burden of proof more difficult for employees. Finally, Thorne concluded that rather than simply proving that working conditions were intolerable, some employees must also show that the employer knew about the poor conditions and could have remedied the situation [20].

Conclusions and Recommendations. What Actions has been taken by business organizations to address the practice of Constructive Discharge?

Because of the costly and time-consuming lawsuit, organization such as the Society for Human Resource Management (SHRM), the HRN Management Group and various employment organizations which works with legislator, lawyers and human resource specialist have develop guidelines to address the constructive discharge practice (HRN Management Group, n.d.). These guidelines have been incorporated by the organizations internal human resource departments. HRN Management has also provided the actions that business organizations have taken to stop the practice of constructive discharge (HRN Management Group, n.d.). These actions are as follows:

1. Ensure that all employment decisions are business related

2. Ensure that employee treatment is consistent across the organization.

3. Avoid even the appearance of retaliation.

4. Be honest. Don't "test the waters" to see if an employee will quit. If you feel you have legitimate reasons for the termination and appropriate actions have been taken, proceed.

5. Obtain written resignation statements from employees.
6. If a layoff is anticipated, implement a voluntary retirement or resignation program before identifying who will be terminated. Also, offer voluntary termination options to entire departments or groups, not just to those who would most likely be fired.

7. Plan well and appropriately document all layoff decisions.

8. Have your attorney draft appropriate releases/waivers of claims.

References

1. Bachman, E (2020) The Differences Between Workplace Bullying And A "Hostile Work Environment" Forbes Magazine Aug 11, 2020. URL: https://www.forbes.com/sites/ericbachman/2020/08/11/the-differencesbetween-workplace-bullying-and-a-hostile-workenvironment/?sh=32a40ee613f2

2. Brady, J (2007) Age of Betrayal: The Triumph of Money in America, 1865-1900, PenguinRandom House New York City, 1-707.

3. Britannica, T. Editors of Encyclopedia (2018, April 12). Conspiracy. Encyclopedia Britannica. URL: https://www.britannica.com/topic/conspiracy

4. Cambridge Dictionary (n.d.) Mindset. In: Dictionary.cambridge.org. Retrieved December 17, 2020, from https://dictionary.cambridge.org/us/ dictionary/english/mindset

5. Dichter, S. F. (1992) The Organization of the '90s Mckinsey p 2 Retrieved from https://www.mckinsey.com/business-functions/organization/ our-insights/the-organization-of-the-90s

6. Doerflinger, J. T., \& Gollwitzer, P. M. (2020). Emotion emphasis effects in moral judgment are moderated by mindsets. Motivation \& Emotion. Retrieved from https://doi.org/10.1007/s11031-020-09847-1

7. Doyle, A (2020) What Is a Constructive Discharge? The Balance Career, https://www.thebalancecareers.com/what-is-constructive-discharge2061654

8. Dweck, C (2007) Mindset: The New Psychology of Success. Random House publishing, NewYork City. EEOC (n.d.) Title VII of the Civil Rights Act of 1964 https://www.eeoc.gov/statutes/title-vii-civil-rights-act-1964

9. England, D (n.d.) Constructive Discharge: Were You Forced to Resign? URL: https://www.nolo.com/legal-encyclopedia/constructive-dischargewere-you-forced-resign.html

10. French II, Robert. (2016). The fuzziness of mindsets: Divergent conceptualizations and characterizations of mindset theory and praxis. International Journal of Organizational Analysis. 24. 673-691. 10.1108/IJOA09-2014-07

11. Funk, Ken (March 2001). What is a Worldview? http://web.engr.oregonstate.edu/ funkk/Personal/worldview.html

12. Gollwitzer, Peter. (2012). Mindset theory of action phases. 10.4135/9781446249215.n26

13. Gordon, S (2020) 6 Reasons Why People Are Bullied at Work, Very Wellmind, URL: https://www.verywellmind.com/reasons-whyworkplace-bullies-target-people-460783

14. Green v Brannan (2016) US. Supreme Court 578 USHRN Management Group (n.d.) Constructive Discharge: How Can We Be Sued If An Employee Quits? White Paper, URL: https://www.hrperformancesolutions.net/ files/cusg2011/1033/file/whitepapers/pdf/WhitePaper-ConstructiveDischarge.pdf

15. Mindset. (2020, December 4). In: Wikipedia. https://en.wikipedia.org/ wiki/Mindset\#cite note-1

16. Namie, $\bar{G}$ and Namie R, (n.d.) Workplace Bullying Institute (WBI) URL: https://workplacebullying.org/

17. Naughton, J. (2012) New-tech moguls: the modern robber barons? The Guardian, p 5-6. Retrieved from https://www.theguardian.com/ technology/2012/jul/01/new-tech-moguls-robber-barons

18. Post, M (2020) Terrorized by a Hostile Work Environment? 7 Essential Tips for 2020! Forensic Notes: https://www.forensicnotes.com/ dealing-with-a-hostile-work-environment/

19. Pride, W. M., Hughes, R. J. Hughes, Kapoor J. R. Kapoor, (2015) Foundations of Business Cengage. Boston, MA

20. Thorne, J.D. (1994) "Who Says Quitters Never Win?" Small Business Reports. October.

21. The Free Dictionary (nd) Mindset Retrieved December 17, 2020 from: https://www.thefreedictionary.com/mindset\#: :text=mind\%C2\%B7set\&text=

22. Sources of Insight (n.d.) Mindset Defined. Retrieved December 17, 2020, from: https://sourcesofinsight.com/what-is-Mindset/\#: :text=Mindset \%20Defined, \%2C\%20\%E2\%80\%9CWhat $\% 20$ is $\% 20$ Mindset $\% 3 F \% E 2 \% 80 \%$ 9D\&text=The $\% 20$ ideas $\% 20$ and\%20attitudes\%20with,(World\%20English\% 20Dictionary.)

23. Wessel, D (2018) Is Lack of Competition Strangling the U.S. Economy? Retrieved from URL: https://hbr.org/2018/03/is-lack-ofcompetition-strangling-the-u-s

24. Yahnke, K (2019) What is a Hostile Work Environment? https://isight.com/resources/the-complete-guide-to-a-hostile-work-environment/

Received: December 03, 2021 Approved for printing: December 29, 2021 Published: January 31, 2022 
Вісник Київського національного університету імені Тараса Шевченка.

Державне управління, 1(15), 28-32.

Удк: 351

DOI: https://doi.org/10.17721/2616-9193.2022/15-6/9

Лестер С. Рімс, проф., д-р наук з держ. упр., д-р юрид. наук

Університет Маунт-Сент-Мері, Лос-Анджелес, Каліфорнія, США

https://orcid.org/0000-0002-6883-7072

email: Ireams@msmu.edu

\section{МИСЛЕННЯ, ЩО СТОЇТЬ ЗА ТИХОЮ ДИСКРИМІНАЦІЄЮ \\ ТА ЗМОВОЮ ЩОДО КОНСТРУКТИВНОГО ЗВІЛЬНЕННЯ}

Протягом багатьох років працівники стикалися з ситуаціями, коли їхні дії, які раніше отримували схвалення, тепер розелядалися як руйнівні. Змінилися стандарти ефективності та оцінювання, тому працівник вважається недостатньо продуктивним. Колеги, які колись підтримували, стають віддаленими, критичними або уникають взаємодії. Через ці зміни працівник приймає рішення про звільнення через нестерпні умови праці, що дозволяє керівництву зробити висновок про вину працівника. У статті аналізується ділове мислення вищого керівництва, яке задіяне в мовчазній дискримінаційній змові щодо конструктивного звільнення. Проаналізовано психологічні, когнітивні, правові та економічні фактори з використанням теорії обґрунтування, тематичних досліджень, правового та управлінського аналізу. На основі обговорення правового та виробничого середовища, автор формулює рекомендації для реалізації бізнесу та державних установ.

Ключові слова: ділове мислення, конструктивне звільнення, бізнес- і державні установи, управління людським капіталом. 